ISSN 2623-6575

GLASILO

UDK 631

UDK 630

UDK 502.1

FUTURE

UDK 008
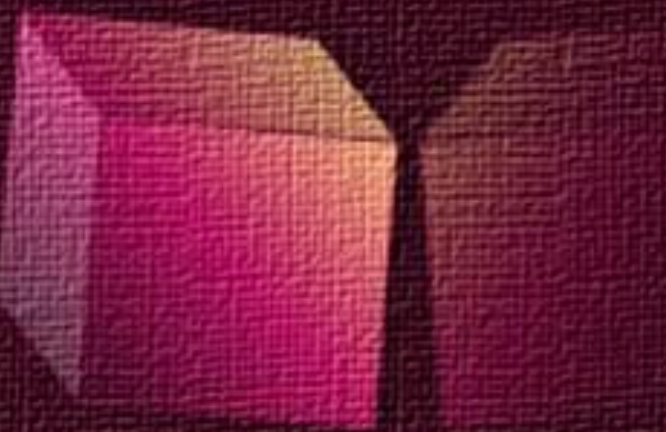

VOLUMEN 1 BROJ 3

KOLOVOZ 2018. 


\section{Glasilo Future}

\section{Stručno-znanstveni časopis}

Nakladnik:

FUTURA

\section{FUTUR}

Sjedište udruge: Šibenik

\section{Adresa uredništva:}

Bana Josipa Jelačića 13 a, 22000 Šibenik, Hrvatska / Croatia

留 / 圆: +385 (0) 022218133

凹: urednistvo@gazette-future.eu / editors@gazette-future.eu

(3): www.gazette-future.eu

\section{Uređivački odbor / Editorial Board:}

Doc. dr. sc. Boris Dorbić, v. pred. - glavni i odgovorni urednik / Editor-in-Chief

Emilija Friganović, dipl. ing. preh. teh., v. pred. - zamjenica g. i o. urednika / Deputy Editor-in-Chief

Ančica Sečan Matijaščić, univ. bacc. act. soc. - tehnička urednica / Technical Editor

Antonia Dorbić, mag. art. - zamjenica tehničke urednice / Deputy Technical Editor

Prof. dr. sc. Željko Španjol

Mr. sc. Milivoj Blažević

Vesna Štibrić, dipl. ing. preh. teh.

\section{Međunarodno uredništvo / International Editorial Board:}

Prof. dr. sc. Kiril Bahcevandziev - Portugal (Instituto Politécnico de Coimbra)

Prof. dr. sc. Martin Bobinac - Srbija (Šumarski fakultet Beograd)

Doc. dr. sc. Zvezda Bogevska - Makedonija (Fakultet za zemjodelski nauki i hrana Skopje)

Dario Bognolo, mag. ing. - Hrvatska (Veleučilište u Rijeci)

Prof. dr. sc. Agata Cieszewska - Poljska (Szkoła Główna Gospodarstwa Wiejskiego w Warszawie)

Prof. dr. Bogdan Cvjetković, prof. emeritus - Hrvatska (Agronomski fakultet Zagreb)

Prof. dr. sc. Duška Ćurić - Hrvatska (Prehrambeno-biotehnološki fakultet Zagreb)

Doc. dr. sc. Margarita Davitkovska - Makedonija (Fakultet za zemjodelski nauki i hrana Skopje)

Doc. dr. sc. Dubravka Dujmović - Hrvatska (Agronomski fakultet Zagreb)

Prof. dr. sc. Semina Hadžiabulić - Bosna i Hercegovina (Agromediteranski fakultet Mostar)

Prof. dr. sc. Péter Honfi - Mađarska (Faculty of Horticultural Science Budapest)

Prof. dr. sc. Valeria Ivanova - Bugarska (Fakultet za lozaro - gradinarstvo Plovdiv)

Doc. dr. sc. Orhan Jašić - Bosna i Hercegovina (Filozofski fakultet Tuzla)

Prof. dr. sc. Biljana Lazović - Crna Gora (Biotehnički fakultet Podgorica)

Hrv. akademik prof. dr. sc. Stanislav Nakić - Bosna i Hercegovina (Sveučilište Hercegovina Mostar)

Sandra Popović, mag. ing. - Srbija (Poljoprivredni fakultet Beograd)

Doc. dr. sc. Bojan Simovski - Makedonija (Šumarski fakultet Skopje)

Prof. dr. sc. Davor Skejić - Hrvatska (Građevinski fakultet Zagreb)

Doc. dr. sc. Milan Stanković - Srbija (Univerzitet u Kragujevcu)

Akademik prof. dr. sc. Refik Šećibović - Bosna i Hercegovina (Visoka škola za turizam i menadžment Konjic)

Prof. dr. sc. Andrej Šušek - Slovenija (Fakulteta za kmetijstvo in biosistemske vede Maribor)

Prof. dr. sc. Elma Temim - Bosna i Hercegovina (Agromediteranski fakultet Mostar)

Doc. dr. sc. Ivana Vitasović Kosić - Hrvatska (Agronomski fakultet Zagreb)

Doc. dr. sc. Ana Vujošević - Srbija (Poljoprivredni fakultet Beograd)

Prof. dr. sc. Vesna Židovec - Hrvatska (Agronomski fakultet Zagreb)

Lektura i grafička priprema: Ančica Sečan Matijaščić, univ. bacc. act. soc.

Objavljeno: 18. kolovoza 2018. godine.

Časopis izlazi u elektroničkom izdanju dva puta godišnje, krajem lipnja i prosinca, a predviđena su i dva

interdisciplinarna specijalna izdanja tijekom godine iz STEM i ostalih znanstvenih/umjetničkih područja.

Časopis je besplatan.

Rukopisi i recenzije se ne vraćaju i ne honoriraju.

Umnožavanje (reproduciranje), stavljanje u promet (distribuiranje), priopćavanje javnosti, stavljanje na raspolaganje javnosti odnosno prerada u bilo kojem obliku nije dopuštena bez pismenog dopuštenja Nakladnika. Sadržaj objavljen u Glasilu Future može se slobodno koristiti u osobne i obrazovne svrhe uz obvezno navođenje izvora. 


\section{Glasilo Future}

\section{Stručno-znanstveni časopis}

FUTURA - stručno-znanstvena udruga za promicanje održivog razvoja, kulture i međunarodne suradnje, Bana Josipa Jelačića 13 a, 22000 Šibenik, Hrvatska

(2018) 1 (3) 01-75

\section{SADRŽAJ:}

Izvorni znanstveni rad (original scientific paper)

Str.

E. Delić, Jasnica Medak, Azra Bakrač, Subha Džafić, B. Dorbić, Berina Muhović

Dendroflora Gradskog parka u Bihaću

Woody Plants in the Bihać City Park

\section{Pregledni rad (scientific review)}

Martina Rubě̌a

Digitalne nejednakosti i potencijal za socijalno uključivanje

Digital Inequalities and Potential for Social Inclusion

Ančica Sečan Matijaščić

Pravo na privatnost i objavljivanje osobnih podataka, informacija (o) i fotografija maloljetne djece

The Right to Privacy and Publishing of Personal Data, Information (about) and

Photographs of Minor Children

\section{Nekategorizirani rad (uncategorised paper)}

Nina Gojić

Prikaz predstave

Play review

\section{B. Dorbić}

Prikaz knjige

Book review

D. Crnogaća, M. Chiabov, Ana Selak

Prikaz radova natječaja

Competition proposals review 


\title{
Digitalne nejednakosti i potencijal za socijalno uključivanje
}

\section{Digital Inequalities and Potential for Social Inclusion}

\author{
Martina Rubeša ${ }^{1 *}$
}

pregledni rad (scientific review)

\section{Sažetak}

Razvojem tehnologije i njenom sve većom prisutnošću u svakodnevnom životu, u porastu je i digitalna nejednakost. Kao oblik postojećih društvenih nejednakosti, digitalna nejednakost manifestira se u dva aspekta. Prvi se odnosi na mogućnost fizičkog pristupa Internetu a drugi na razlike u načinima iskorištavanja mogućnosti koje Internet i suvremene tehnologije pružaju, što je povezano s obrazovanjem, razvijenosti digitalnih kompetencija, društvenim vezama itd. U središtu ovog rada je uloga digitalnih tehnologija u odnosu na sposobnost ljudi da sudjeluju u društvu. Obzirom da se razlike u digitalnim vještinama kojima pojedinci raspolažu sve više povećavaju, mnogima prijeti socijalna isključenost. $U$ radu se preko definiranja pojma digitalne nejednakosti te obilježja digitalne kompetencije daje pregled stupnja razvijenosti digitalnih vještina u Europskoj uniji i Hrvatskoj. Nadalje se pojašnjavaju ekonomski, društveni, tehnološki i politički čimbenici kao najzastupljeniji uzroci koji dovode do nejednakosti i odražavaju stupanj socijalne isključenosti. Pojašnjavaju se implikacije i prikaz mogućnosti prevladavanja digitalne nejednakosti.

Ključne riječi: digitalna nejednakost, digitalna podjela, digitalna kompetencija, Internet, socijalna isključenost.

\begin{abstract}
With the development of technology and its growing presence in everyday life, digital inequality is expanding. As a form of existing social inequality, digital inequality manifests in two aspects. The first relates to the possibility of physical access to the Internet and the other concerns the disparities in how individuals are using the possibilities of the Internet and the communication technology, which is related to education, the development of digital competences, social bonds, etc. The focus of this paper is the role of digital technologies in relation to people's ability to participate in society. Considering the differences in digital skills among individuals, many are at risk of social exclusion. Through the

\footnotetext{
${ }^{1}$ Studijski centar socijalnog rada pri Pravnom fakultetu Sveučilišta u Zagrebu, Nazorova 51, 10000 Zagreb, Hrvatska.

* Martina Rubeša, univ. bacc. act. soc., e-mail: martina.rubesa@gmail.com, studentica diplomskog studija Socijalne politike, rad je nastao na temelju seminarskog rada iz kolegija "Socijalna politika i socijalni razvoj" pod mentorstvom doc. dr. sc. Tea Matkovića.
} 
definition of the concept of digital inequality and the areas of digital competence, this paper gives an overview of the degree of digital skills development in the European Union and Croatia. Furthermore, the economic, social, technological and political factors are explained as the most common causes that lead to inequality and reflect the degree of social exclusion. The implications and possibilities of overcoming digital inequality are explained.

Key words: Digital Inequality, Digital Divide, Digital Competence, Internet, Social Exclusion.

\section{Uvod}

Sve prisutnije korištenje Interneta i digitalnih tehnologija transformirajući procese obrazovanja, poslovanja, participacije u političkom i društvenom životu obogaćuje ljudski i socijalni kapital. Društvo sve više napreduje razvijajući nove tehnologije koje implementira u radne procese, organizacije, procese stjecanja znanja i razmjene informacija. Javna uprava putem tehnologije ispostavlja nove usluge istodobno pružajući građanima mogućnost participiranja u političkom životu (putem instrumenta e-savjetovanja). Međutim, oni koji nemaju pristup ili ne posjeduju potrebne vještine u riziku su od društvene izoliranosti i isključenosti koje nastaju kao posljedica tzv. digitalne podjele. Za primjer, imaju manje mogućnosti pretraživati stranice poput "Moj-posao" i slati zamolbe za posao ili naručivati se na pregled u bolnicu online i prijaviti se na listu čekanja, što predstavlja značajnu prepreku. OECD sveobuhvatno definira digitalnu podjelu kao "raskorak u korištenju i pristupu informacijama i komunikacijskim tehnologijama (ICT), te korištenju Interneta za različite aktivnosti. Obuhvaća pojedince, zajednice, zaposlene i nezaposlene, te poduzeća i zemljopisna područja čija se sposobnost da iskoriste prednosti interneta znatno se razlikuje" (OECD, 2001, prema EPRS, 2015, str. 2). Koncept digitalne podjele mijenjao se kroz vrijeme te se u začecima proučavanja ovoj pojavi pristupilo kroz prizmu dihotomije mogućnosti pristupanja i korištenja Interneta na one koji imaju/nemaju pristup odnosno koriste/ne koriste Internet (Di Maggio i Hargittai, 2001; Di Maggio et al., 2004; Vrkić Dimić, 2014). Tako DiMaggio et al. (2004) govore o "razlici između ljudi koji koriste web i druge internetske usluge (osobito e-mail) i koji to ne čine" (DiMaggio et al., 2004, str. 8). No s obzirom na to da će primjerice pojedinci s višim stupnjem digitalne pismenosti biti u mogućnosti više iskoristiti prednosti Interneta, u kasnijim razmatranjima pojam digitalne podjele više se povezuje $\mathrm{s}$ razlikama u vještinama i poznavanju digitalnih tehnologija kojima pojedinci raspolažu. Van Dijk smatra da se digitalna podjela može shvatiti kao "nejednakosti u četiri područja: motivaciji, fizičkom pristupu, digitalnim vještinama i različitoj upotrebi" (van Dijk, 2012, str. 57). Di Maggio i Hargittai (2001) uvode pojam "digitalnih nejednakosti" kojim žele naglasiti multidimenzionalnost (i društvenih) nejednakosti koje proizlaze iz postojanja specifičnih razlika između pojedinaca u njihovim mogućnostima i sposobnostima usvajanja digitalnih kompetencija. Digitalna nejednakost ustvari je oblik društvene nejednakosti odnosno razlika u posjedovanju digitalnih vještina, a ljudi se razlikuju vještinama kojima raspolažu. Buhtz (2017) navodi podjelu digitalne nejednakosti na onu "prvog reda", koja se odnosi na razlike u pristupu i 
korištenju digitalnim tehnologijama, te "drugog reda", koja se bavi pitanjem na koji način pojedinci koriste digitalne tehnologije, odnosno koliko svrsishodno. U pravilu osobe nižeg socioekonomskog statusa imaju manju mogućnost pristupa Internetu od onih u boljem položaju zbog primjerice visokih cijena elektroničke opreme i pretplate. Obzirom da digitalna nejednakost odražava već postojeće društvene nejednakosti, razumijevanje tog koncepta relevantno je s aspekta kreiranja politika kojima bi se digitalna podjela prevladala ili barem ublažila i na taj način prevenirao problem socijalne isključenosti. U nastavku rada biti ce govora o digitalnoj kompetenciji, potom slijedi osvrt na stanje ljudskog kapitala odnosno razvijenost digitalne pismenosti u Europi i Hrvatskoj, zatim će se preko pojašnjenja čimbenika digitalne nejednakosti i njenim implikacijama doći do prikaza pojedinih mjera koje bi pomogle ublažiti posljedice digitalnih nejednakosti te naposljetku zaključka.

\section{Digitalna kompetencija}

Prilično je izvjesno da će vještine koje su danas tražene na tržištu rada te kojima kojima pojedinac raspolaže vremenom zastarijevati te postati nedostatne s obzirom na ubrzani razvoj tehnologija $\mathrm{i}$ prateće promjene. Stoga je razumno ustvrditi kako ih je nužno kontinuirano nadograđivati. Međutim, pitanje digitalne kompetencije šire je od svođenja na zastarijevanje u vremenu jer, primjerice, iako današnje generacije odrastaju uz Internet njihove se vještine često procjenjuju nedostatnima. Prema podatcima Izvješća o digitalnom napretku Europe (2017) čak 44 \% građana Europske unije nema osnovne digitalne vještine. Digitalna kompetencija jedna je od osam ključnih vještina cjeloživotnog obrazovanja unutar Okvira ključnih kompetencija za cjeloživotno učenje koja uključuje "kritičko razmišljanje i sigurnu upotrebu digitalne tehnologije u svim aspektima života, a podrazumijeva pet područja" (Europska komisija, 2013) prikazanih u Tablici 1. Tablica 2. sadrži detaljan popis vještina koje čine osnovu digitalne nejednakosti. Naime, Europska komisija je za cilj postavila izgradnju inkluzivnog digitalnog društva kako bi odgovorila na brojne izazove procesa globalizacije. Stoga je razvoj vještina digitalne kompetencije postavila kao jedan od prioriteta politika Europske unije, a to potvrđuje i u svojim dokumentima (Europa 2020, Digital Agenda for Europe, Digital Single Market Strategy).

Tablica 1. Operacionalizacija područja digitalne kompetencije (Europska komisija, 2013).

Table 1. Operationalization of Digital Competence Areas (European Commission, 2013).

\begin{tabular}{|l|l|}
\hline Područja digitalne kompetencije & Odnosi se na \\
\hline Komunikacija i suradnja & $\begin{array}{l}\text { komunikaciju u digitalnome okruženju, dijeljenje resursa pomoću online } \\
\text { alata, suradnju kroz digitalne medije, interakciju i svijest o međukulturalnosti }\end{array}$ \\
\hline $\begin{array}{l}\text { Informacijska i podatkovna } \\
\text { pismenost }\end{array}$ & $\begin{array}{l}\text { znanja izrade i uređivanja sadržaja (tekst, slike, video), stvaranje kreativnih } \\
\text { multimedijskih uradaka, programiranje, primjenu prava intelektualnog } \\
\text { vlasništva i licence }\end{array}$ \\
\hline $\begin{array}{l}\text { Informacijska i podatkovna } \\
\text { pismenost }\end{array}$ & $\begin{array}{l}\text { pronaći, pohraniti, organizirati i analizirati digitalne informacije, prema } \\
\text { njihovoj važnosti i svrsi }\end{array}$ \\
\hline Sigurnost & $\begin{array}{l}\text { osobna zaštita, zaštita podataka, zaštita digitalnog identiteta, mjere } \\
\text { sigurnosti, sigurno i održivo korištenje }\end{array}$ \\
\hline Rješavanje problema & $\begin{array}{l}\text { utvrditi digitalne potrebe i resurse, odabirati odgovarajuće digitalne alate s } \\
\text { obzirom na namjenu ili potrebu, rješavati konceptualne probleme putem } \\
\text { digitalnih sredstava, kreativno koristiti tehnologiju, rješavati tehničke probleme }\end{array}$ \\
\hline
\end{tabular}


Tablica 2. Okvir digitalne kompetencije (Europska komisija, 2013).

Table 2. Digital competence framework (European Commission, 2013).

\begin{tabular}{|c|c|}
\hline Područja digitalne kompetencije & Vještine \\
\hline Komunikacija i suradnja & $\begin{array}{l}\text { Interakcija putem tehnologije } \\
\text { Komunicirati kroz različite digitalne uređaje i aplikacije, razumjeti kako se } \\
\text { ostvaruje digitalna komunikacije te načine komuniciranja putem digitalnih } \\
\text { sredstava, razlikovati komunikacijske formate, prilagoditi načine } \\
\text { komunikacije i strategije određenoj publici. } \\
\text { Razmjena informacija i sadržaja } \\
\text { Podijeliti s drugima mjesto i sadržaj pronađene informacije, spremnost i } \\
\text { sposobnost za razmjenu znanja, sadržaja i resursa, biti proaktivan u širenju } \\
\text { vijesti, sadržaja i resursa, znati kako se citiraju informacije, integrirati nove } \\
\text { podatke u postojeća znanja. } \\
\text { Uključenje u online društvo } \\
\text { Sudjelovati u društvu kroz online angažman, tražiti mogućnosti za vlastiti } \\
\text { razvoj i osnaživanje u korištenju tehnologije i digitalnog okruženja, biti } \\
\text { svjestan potencijala za sudjelovanje pojedinca pomoću tehnologije. } \\
\text { Suradnja putem digitalnih kanala } \\
\text { Koristiti tehnologiju i medije za timski rad i suradnju, zajednička izgradnja i } \\
\text { stvaranje resursa, znanja i sadržaja. } \\
\text { Pravila lijepog ponašanja na Internetu } \\
\text { Znati i primjenjivati norme ponašanja u online/virtualnom okruženju, } \\
\text { biti svjestan kulturoloških raznolikosti, zaštititi sebe i druge od mogućih } \\
\text { online opasnosti (npr. zlostavljanje putem Interneta), razviti aktivne } \\
\text { strategije otkrivanja neprimjerenog ponašanja. } \\
\text { Upravljanje digitalnim identitetom } \\
\text { Stvoriti, prilagoditi i upravljati jednim ili više digitalnih identiteta, zaštititi } \\
\text { svoj e-ugled, raditi s podatcima kreiranim kroz više osobnih računa i aplikacija. }\end{array}$ \\
\hline Stvaranje digitalnog sadržaja & $\begin{array}{l}\text { Razvoj sadržaja } \\
\text { Stvarati sadržaje u različitim formatima uključujući multimediju i poboljšati } \\
\text { razvijene sadržaje, kreativno se izraziti putem digitalnih medija i tehnologije. } \\
\text { Integriranje i ponovno razrađivanje } \\
\text { Mijenjati, poboljšavati i kombinirati postojeće resurse za stvaranje novih, } \\
\text { izvornih i relevantnih sadržaja i znanja. } \\
\text { Autorska prava i dozvole } \\
\text { Primjenjivati prava intelektualnog vlasništva i licence na informacije i sadržaj. } \\
\text { Programiranje } \\
\text { Primjenjivati postavke, modificirati programe, programirati aplikacije i } \\
\text { uređaje, razumjeti načela programiranja. }\end{array}$ \\
\hline $\begin{array}{l}\text { Informacijska i podatkovna } \\
\text { pismenost }\end{array}$ & $\begin{array}{l}\text { Pregledavanje, pretraživanje i filtriranje informacija } \\
\text { Pretraživati i pristupati informacijama online, iskazati potrebu za informa- } \\
\text { cijom, učinkovito pronaći resurse, kretati se između raznih online izvora. } \\
\text { Vrednovanje informacija } \\
\text { Sakupiti, obraditi, razumjeti i kritički vrednovati informacije. } \\
\text { Pohrana i pronalaženje informacija } \\
\text { Manipulirati i pohranjivati informacije i sadržaje za lakše pretraživanje, } \\
\text { organizirati informacije i podatke. }\end{array}$ \\
\hline Sigurnost & $\begin{array}{l}\text { Zaštita uređaja } \\
\text { Zaštititi svoje uređaje i razumjeti online rizike i prijetnje, razumjeti potrebu } \\
\text { provođenja sigurnosnih mjera. } \\
\text { Zaštita osobnih podataka } \\
\text { Razumjeti uobičajene uvjete korištenja/pružanja usluge, zaštititi osobne } \\
\text { podatke, poštivati privatnost drugih, zaštititi se od online prijevara, prijetnji } \\
\text { i virtualnog zlostavljanja. } \\
\text { Zaštita zdravlja } \\
\text { Poznavati zdravstvene rizike povezane s korištenjem tehnologije u smislu } \\
\text { fizičkog i psihičkog zdravlja. } \\
\text { Zaštita okoliša } \\
\text { Biti svjestan utjecaja ICT-a na okoliš. }\end{array}$ \\
\hline
\end{tabular}




\begin{tabular}{|l|l|}
\hline Područja digitalne kompetencije & Vještine \\
& Rješavanje tehničkih problema \\
Identificirati moguće probleme (od jednostavnih problema u radu do \\
rješavanja složenijih problema) i rješavati ih pomoću digitalnog sredstva. \\
Prepoznavanje potreba \\
Procijeniti vlastite potrebe u smislu resursa, alata i razvoja kompetencija, \\
povezati potrebe s mogućim rješenjima, prilagođavati alate za osobne \\
potrebe, kritički procijeniti moguća rješenja i digitalne alate. \\
Inovacije i kreativno korištenje tehnologije \\
Koristiti tehnologiju kreativno/inovativno, surađivati u izradi digitalnih i \\
multimedijskih sadržaja, kreativno se izraziti kroz digitalne medije i \\
tehnologiju, stvarati znanje i rješavati konceptualne probleme pomoću \\
digitalnih alata. \\
Prepoznavanje potrebe unaprjeđivanja digitalne kompetencije \\
Prepoznati potrebu unaprjeđivanja vlastite razine digitalne kompetencije u \\
skladu s novim potrebama i tehnologijama, podržati razvoj digitalne \\
kompetencije drugih pojedinaca.
\end{tabular}

Ovladavanjem vještina digitalne kompetencije ljudi mogu bolje iskoristiti pogodnosti koje nudi digitalno okruženje ali i umanjiti potencijalne rizike.

\section{Razvijenost digitalnih vještina u Europi}

Europska komisija razvila je indeks digitalnoga gospodarstva i društva (DESI) kojim se mjeri digitalni napredak na temelju pet pokazatelja (Tablica 3.).

Tablica 3. Pokazatelji indeksa digitalnog gospodarstva i društva (Europska komisija, 2017a). Table 3. Indicators of the Digital Economy and Society Index (European Commission, 2017a).

\begin{tabular}{|l|l|}
\hline Povezivost & $\begin{array}{l}\text { fiksna širokopojasna mreža, mobilna širokopojasna mreža, brzina i cijene } \\
\text { širokopojasnog pristupa }\end{array}$ \\
\hline Ljudski kapital & upotreba Interneta; osnovne i napredne digitalne vještine \\
\hline Korištenje Internetom & $\begin{array}{l}\text { koliko se građani služe internetskim sadržajem i sudjeluju u komunikaciji } \\
\text { ili transakcijama na Internetu }\end{array}$ \\
\hline Integracija digitalne tehnologije & digitalizacija poduzeća i e-trgovina \\
\hline Digitalne javne usluge & e-uprava \\
\hline
\end{tabular}

Vezano uz stanje u Europskoj uniji i Hrvatskoj, vodit ćemo se podatcima Izvješća o digitalnom napretku Europe (2017.) "kojim se prati napredak država članica u pogledu njihove digitalizacije i u ovisnosti je o politikama specifičnima za pojedinu zemlju" (Europska komisija, 2017a, str. 1).

Generalno gledajući Danska, Finska i Švedska imaju najnaprednije digitalne ekonomije dok Rumunjska, Bugarska i Grčka imaju najniže rezultate na indeksu. Promatrano prema pojedinim područjima indeksa, najbolji pristup Internetu imaju Nizozemska, Luksemburg i Belgija. U pogledu ljudskog kapitala, od osnovnih korisničkih vještina koje omogućavaju konzumiranje digitalnih dobara i usluga do naprednih vještina koje služe povećanoj produktivnosti i gospodarskom rastu (Europska komisija, 2017a) Danska, Luksemburg i Finska imaju najviše rezultate, a Rumunjska, Bugarska, Grčka i Italija najniže. Aktivnosti variraju od surfanja videa, glazbe, igara do komunikacijskih aktivnosti (npr. putem video konferencija, skype poziva) ili online kupovine i bankarstva. Po pitanju 
integracije digitalne tehnologije u poslovne procese (korištenju oblaka, razvijenosti digitalnih financijskih transakcija i dr.) Danska, Finska i Švedska ostvaruju najviše koristi, dok u Rumunjskoj, Bugarskoj i Mađarskoj više od $50 \%$ poduzeća ulaganje u digitalne tehnologije "svodi samo na posjedovanje nekoliko računala i jednostavne web stranice" (Europska komisija, 2017a, str. 2). Euprava najrazvijenija je u Danskoj, Finskoj i Švedskoj, dok su Rumunjska, Bugarska, Grčka i Italija na dnu ljestvice. Prema podatcima Izvješća (Europska komisija, 2017a, str. 5) "uočljivo je napredovanje u korištenju e-uprave među mladima svih razina obrazovanja, što znači da njihove aktivnosti na Internetu nisu ograničene samo na društvene medije i potrošnju digitalnog sadržaja, nego se proširuju i na korištenje složenijih usluga".

Slika 1. Digitalni razvoj Europe (Europska komisija, 2017a).

Figure 1. Digital Development of Europe (European Commission, 2017a).

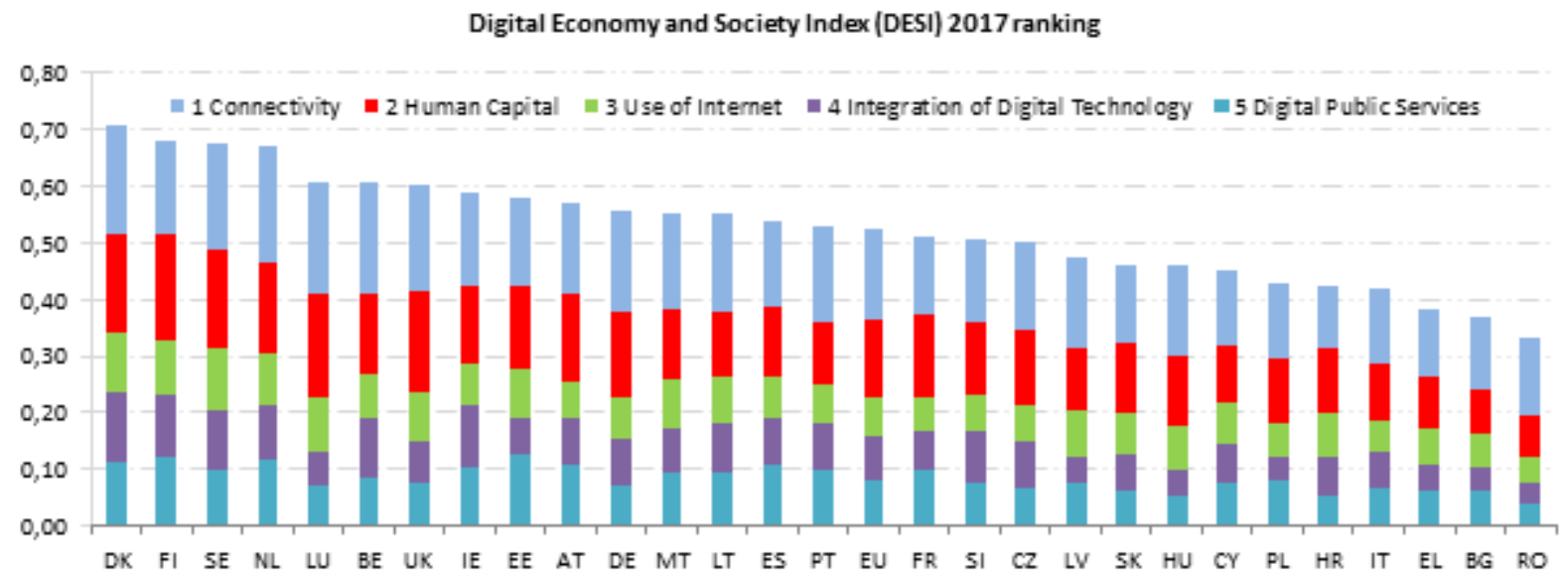

Slika 2. Postotak osoba koje nikada nisu koristile Internet (Eurostat, 2017).

Figure 2. Percentage of people who have never used the Internet (Eurostat, 2017).

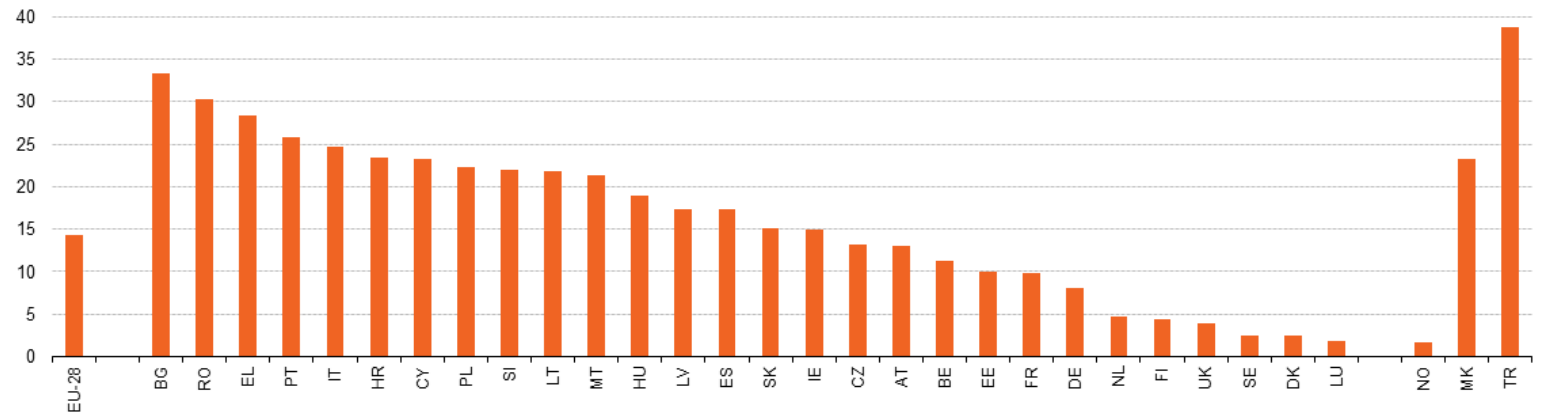

Zanimljivo je da je za područje Europske unije karakteristična duboka "digitalna podjela" između država članica obzirom na razinu ne-korištenja Interneta (Slika 2.). Naime, najveći je udio onih koji nikada nisu koristili Internet u Bugarskoj (33\%) i Rumunjskoj (30 \%), a najmanji u Luksemburgu i Danskoj (2 \%). Podatci pokazuju kako čak $23 \%$ građana Hrvatske nikada nije koristilo Internet, u usporedbi s prosjekom u državama članicama koji iznosi 14 \% (Eurostat, 2017.), što je poražavajuće. Nešto više riječi o tome biti će u nastavku rada. 


\section{Razvijenost digitalnih vještina u Hrvatskoj}

Prema Izvješću o digitalnom napretku Europe, profil Hrvatske (2017), Hrvatska je ostvarila zamjetan napredak, no ostale države napredovale su brže. Kako pokazuje grafikon (Slika 1.), Hrvatska zauzima 24. mjesto od 28 zemalja članica po indeksu digitalne razvijenosti. Grafikon (Slika 3.) pokazuje stanje digitalnog razvoja po pojedinim područjima u usporedbi s prosjekom ostalih država članica. Naime, građani Hrvatske služe se Internetom više od prosjeka, a podatci (Državni zavod za statistiku, 2016; Eurostat, 2017; Europska komisija, 2017a) pokazuju da se digitalne vještine neprestano poboljšavaju. Upotreba digitalnih tehnologija u poduzećima gotovo je na razini prosjeka, no broj korisnika e-uprave vrlo sporo se povećava i nema napretka u pogledu pružanja usluga od strane javne uprave (Europska komisija, 2017a).

Slika 3. Digitalni razvoj Hrvatske (Europska komisija, 2017b).

Figure 3. Digital Development of Croatia (European Commission, 2017b).

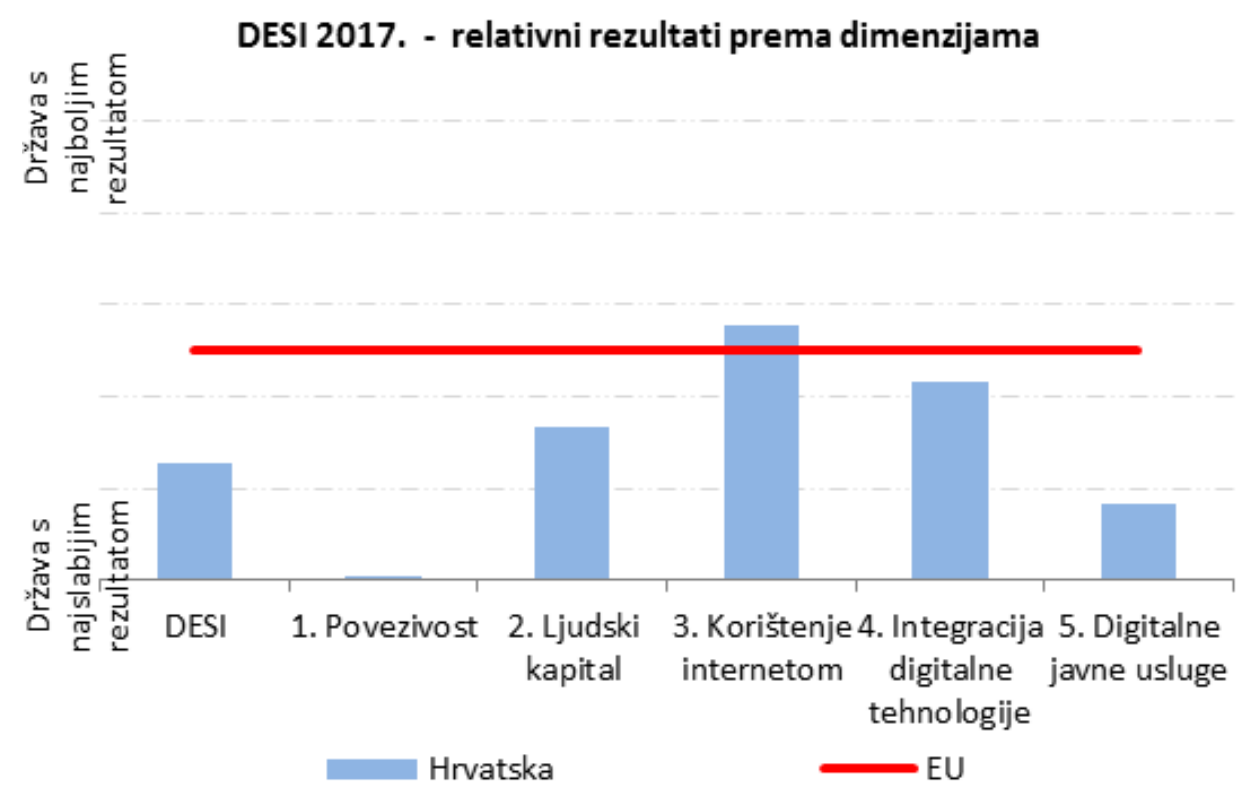

Jedan od najvećih izazova u Hrvatskoj je povezivost zbog ograničenog pristupa u ruralnim područjima, niskoj pokrivenosti brzim Internetom, te visokih cijena pristupa Internetu (Europska komisija, 2017b, Eurostat, 2017). Valja spomenuti kako je Hrvatska država s najskupljom pretplatom za fiksni pristup Internetu u EU. Iz tog razloga veliki broj ljudi nema pristup Internetu, što se podudara s podatcima Eurostata (2017) koji ukazuju kako velik broj građana (23\%) nikada nije niti koristilo Internet. I podatci EUKidsOnline (2014) potvrđuju da je Internet regionalno vrlo nejednako dostupan te da postoje krajevi i kućanstva koja nemaju pristup Internetu, a koji uvelike ovisi i o socioekonomskom statusu kućanstva. U pogledu ljudskog kapitala, vještine se poboljšavaju i raste broj korisnika. Iako 55 \% Hrvata ima barem osnovne digitalne vještine, Hrvatska raspolaže sa svega 3,5 \% stručnjaka ICT područja. 
Vezano uz korištenje Interneta u Hrvatskoj, najviše se čitaju vijesti (91 \%), sluša glazba i igraju igre na Internetu $(85 \%)$ te se koristi za komunikaciju video pozivima (45 \%). $69 \%$ korisnici su društvenih mreža, a služe se i Internet bankarstvom (53 \%) te se Internetom koriste za kupovinu (45 \%) (Europska komisija, 2017b). Slične podatke potvrđuje EUKidsOnline platforma.

U protekloj godini Hrvatska je ostvarila malen napredak po pitanju integracija digitalne tehnologije u poslovanje, no "unatoč nepostojanju nacionalne politika u području digitalizacije, hrvatske su tvrtke među srednje uspješnima" (Europska komisija, 2017b, str. 8). Kada je riječ o e-upravi, Hrvatska je postigla određeni napredak, ali su ostale države napredovale brže i u tom području. "Hrvatska planira razviti dodatne e-aplikacije za građane", a razvoj e-uprave mogao bi donijeti znatne uštede (Europska komisija, 2017b, str. 9).

\section{Čimbenici digitalne nejednakosti}

Pregledom literature ustanovljeno je kako se čimbenici digitalne nejednakosti operacionaliziraju na različite načine, od kojih će biti spomenuti samo neki oko kojih postoji konsenzus. Generalno mogu se podijeliti na ekonomske, društvene, tehnološke i političke.

Ekonomski čimbenici: mnogi autori (DiMaggio et al., 2004; Krištofić, 2007; Helsper, 2008; Stiakakis et al., 2009; van Dijk, 2012; Smahel et al., 2012; Buhtz, 2017) socioekonomski status navode kao jedan od ključnih čimbenika koji vodi do digitalne nejednakosti, a odnosi se prije svega na visinu dohotka građana te je učestalo povezan s nezaposlenošću. No, pored navedenog u ovu skupinu čimbenika potpadaju i cijene tehnologija, ulaganja u edukaciju građana, cijene pristupa Internetu i sl. Drugim riječima, ako pojedinac ima nizak dohodak, cijena računala (ili tableta, mobitela i dr.) je visoka, a pretplata skupa, kako je to slučaj u Hrvatskoj, onda će se zasigurno naći u ekonomski nepovoljnom položaju. Odnosno, nemogućnost direktnog pristupa kao posljedica socioekonomskog statusa može dovesti i do socijalne isključenosti. Također, ekonomski čimbenici podrazumijevaju i promjene na tržištu rada zbog novih tehnologija, gdje vlada potražnja za specifičnim vještinama, kojima ako pojedinac ne raspolaže, velika je vjerojatnost da će ostati bez posla ili ga neće moći pronaći. Razvidno je dakle, da digitalna nejednakost koja proizlazi iz ekonomskih čimbenika nije rezultat individualnih karakteristika osobe, stoga pojedinac sam ne može niti utjecati na njih.

Društveni čimbenici: odnose se ponajprije na individualne karakteristike (dob, spol, motivacija, stupanj obrazovanja) ali i specifičnosti pojedinih društvenih skupina. Van Dijk (2012) tako navodi da digitalne nejednakosti proizlaze iz razlika u socijalnim vezama, odnosima i interakcijama pojedinih društvenih skupina. Tako je primjerice za Rome, migrante, nezaposlene te pripadnike nacionalnih manjina karakteristično da imaju smanjene društvene veze s pripadnicima izvan vlastite zajednice, a kao skupina raspolažu manjim resursima digitalne pismenosti. Po pitanju dobi, mlađe generacije više koriste Internet i digitalne tehnologije i raspolažu višim stupnjem digitalnih vještina od starije populacije. Haddon i Livingstone (2014) u sklopu EUKidsOnline ukazali su na zanimljivu činjenicu 
da $36 \%$ djece izjavljuje kako zna više o Internetu od njihovih roditelja. Promatrajući dobnu strukturu korisnika Interneta u Hrvatskoj, ona je na visokoj razini do 54. godine života, iznad $91 \%$, a zatim, što je dob viša, sve je manji broj korisnika. U pogledu toga situacija je identična kao u drugim državama članicama EU (DSZ, 2016). Istraživanja pokazuju (Krištofić, 2007; Helsper, 2008; Stiakakis et al., 2009; van Dijk, 2012; Smahel et al., 2012; Haddon i Livingstone, 2014) da korištenje Interneta raste sa stupnjem obrazovanja, društvenim statusom i visinom prihoda. Tako primjerice Smahel et al. (2012) zaključuju da djeca čiji roditelji imaju viši stupanj obrazovanja ustvari imaju olakšan pristup tehnologijama, u pravilu su više medijski pismena i intenzivnije koriste Internet. Muškarci češće koriste Internet od žena što pojedini autori atribuiraju (van Dijk, 2012) strahu i osjećaju nesigurnosti kod upotrebe digitalnih tehnologija. No, taj je ishod moguće pripisati i društveno uvjetovanim faktorima poput odgoja u tradicionalnim područjima gdje je "tehnologija rezervirana za muškarce". U EU-28 postoje razlike ( $8 \%$ ) između urbanih i ruralnih područja u pogledu pristupa Internetu, pa tako u velikim gradovima stopa pristupa Internetu iznosi $88 \%$, a u ruralnim područjima (80 \%) (Eurostat, 2017). Tehnološki čimbenici: podrazumijevaju nedostupnost mreže u određenim krajevima, te neujednačeno širenje i upotrebu tehnologija između različitih država i regija, institucija itd. Primjerice, u nedavnom izvještaju Centra za mirovne studije (2016) navodi se kako manje od $10 \%$ učenika u Hrvatskoj ide u škole koje podržavaju digitalnu tehnologiju, a prosjek opremljenosti je jedno računalo na 26 učenika, za razliku od susjedne Slovenije gdje je prosjek 6 učenika po jednom računalu.

Politički čimbenici: su usko povezani uz stupanj razvijenosti demokratičnosti društva, primjerice, koliko vlast dopušta participaciju građana u političkom životu, omogućava li da se organiziraju u online zajednice i djeluju putem društvenih medija [social media (eng.)] ili transparentnost političkih odluka i sl. Za usporedbu s Europskom unijom, u kojoj se u posljednje vrijeme ozbiljno razmatraju mogućnosti provedbe prijedloga građana u procesu donošenja političkih odluka iz postupka sudjelovanja u e-savjetovanju, osobito na lokalnim razinama, vezano uz političke čimbenike digitalne nejednakosti Krištofić (2007, str. 170) navodi primjer Kube u kojoj je "pristup Internetu moguć samo za pojedince na sveučilištu ili za neka radna mjesta, ali individualnog pristupa Internetu nema. Slično je i u Mijanmaru gdje svaki vlasnik računala mora imati licencu i nema javnog pristupa Internetu". Van Dijk (2012) ističe da je digitalna nejednakost posljedica nesudjelovanja u političkoj participaciji.

\section{Implikacije digitalnih nejednakosti}

Digitalne nejednakosti utječu na brojna područja života i dovode do nejednakosti životnih šansi ili pristupa uslugama i tržištu rada. Neke od implikacija razaznaju se u nedostatnom pristupu informacijama o zdravlju i zdravstvenim uslugama, manjoj političkoj participaciji građana u svim ostalim aktivnostima izuzev izlaska na izbore, slabijoj kvaliteti obrazovanja i obrazovnih ishoda (ukoliko škola raspolaže manjim brojem nastavničkog kadra obučenim za digitalno opismenjavanje ili nema računalne opreme). Buhtz (2017) u svojem radu navodi opažanje kako je mnogima pronalazak zaposlenja postao otežan otkad je uvjetovan snalaženjem na internetskim tražilicama i razvijenim 
digitalnim vještinama. Po pitanju poslovanja, danas mnogi pribjegavaju razvoju poslovnih ideja grupnom razmjenom mišljenja i razmatranjem ideja [brainstorming (eng.)] u digitalnim zajednicama, a zatim se tako pripremljen projekt prijavljuje na grupno (masovno) financiranje [crowdfunding (eng.)] čime ostvaruju prednost na tržištu i kreatori su tržišta budućnosti. U tom smislu svako odstupanje od sudjelovanja $u$ društvenim aktivnostima $u$ digitalnom okruženju vodi socijalnoj isključenosti.

\section{Prevladavanje digitalnih nejednakosti}

Politike prevladavanja digitalnih nejednakosti većinom su usmjerene na veću obuhvaćenost i širenje širokopojasnog i brzog Interneta u Europskoj uniji pa tako i u Hrvatskoj. Europska komisija radi na poboljšanju situacije te je stoga određene aktivnosti unaprjeđenja digitalne inkluzije inkorporirala u strateške dokumente Europske digitalne agende i Strategije jedinstvenog digitalnog tržišta. Radi se o preporukama izmjene zakonodavstva država članica, ponudi različitih načina financiranja izgradnje infrastrukture za širokopojasne usluge i istraživačkim projektima. U Hrvatskoj, Vlada bi trebala implementirati Direktivu o smanjenju troškova usluga te osigurati bolju pokrivenosti $4 \mathrm{G}$ mrežama. No, trebalo bi ulagati i u stipendije za studente kako bi ih se privuklo u ICT područje kao i u bolju opremljenost institucija (bolnica, fakulteta); razvoj aplikacija prilagođenih korisnicima [user friendy (eng.)] koje bi olakšale pristup uslugama javne uprave; trebalo bi programe digitalnog opismenjavanja uvesti već u prve razrede osnovne škole te nastaviti provoditi informatičko opismenjavanje starijeg stanovništva (koji su zbog nedostatka financijskih sredstava ukinuti); ulagati u digitalno opismenjavanje žena i djevojčica obzirom da su istraživanja pokazala da se manje služe modernim tehnologijama; te u proračunu planirati jedan iznos kojim bi se financirala pomagala i aplikacije koje bi osobama s invaliditetom omogućile pristup tržištu rada, što je svakako element socijalnog uključivanja.

\section{Zaključak}

Sistematičnim pregledom literature utvrđena su dva aspekta digitalne nejednakosti: prvi se odnosi se na fizički pristup Internetu, kao posljedice ekonomskih čimbenika i razvijenosti digitalne infrastrukture države, dok se drugi odnosi na razlike u mogućnostima korištenja Interneta, što je povezano s obrazovanjem, vještinama, društvenim vezama itd. Usporedo s razvojem tehnologije, u porastu je digitalna nejednakost koja predstavlja društveni izazov budućnosti. Razvoj informatičke tehnologije transformirao je društvo i za pretpostaviti je kako će se ljudi sve više razlikovati stupnjem digitalnih vještina kojima raspolažu. Stoga prijeti rizik socijalne isključenosti za velik kontingent društva obzirom da se nejednakosti produbljuju. Jedan od temeljnih preduvjeta inkluzivnog digitalnog društva je pristup Internetu. Iako su intervencije većinom usmjerene na povećanje pristupa, problem digitalne nejednakosti time ne iščezava, već je nužno i uključivanje u programe informatičke 
pismenosti te edukacije digitalnih vještina kao zaštitni mehanizam od socijalne isključenosti. Stjecanje digitalnih vještina treba započeti u najranijoj dobi i nastaviti tijekom cijelog života. Povećane napore potrebno je usmjeriti u programe digitalne inkluzije žena, što bi u Hrvatskoj podrazumijevalo od kampanja senzibilizacije u smjeru da tehnologije nisu isključivo rezervirane za muški spol, te promijene svijesti poslodavaca, do osnaživanja žena da su sposobne usvojiti znanja digitalnih tehnologija, izgradnje platforme koja bi pripomogla većem sudjelovanju žena do veće vidljivosti programa stjecanja digitalnih vještina koji bi bili subvencionirani od strane lokalne zajednice ili države.

\section{Literatura}

Buhtz, K. (2017). Mechanisms driving technology use in the context of digital inequality: A series of essays on the role of social influence, socio-cognitive processes, and socio-economic determinants, doktorska dizertacija, Faculty of Business Administration and Economics of the University of Passau.

Centar za mirovne studije (2016). Nejednakosti u Hrvatskoj: nejednakosti u obrazovnom sustavu izvještaj sa policy preporukama. Preuzeto 01. 12. 2017. s mrežne stranice Centra za mirovne studije: http://nejednakost.cms.hr/wp-content/uploads/2016/09/NEJEDNAKOSTI-U-HRVATSKOJOBRAZOVANJE-.pdf.

DiMaggio, P \& Hargittai, E. (2001). From the 'Digital Divide' to 'Digital Inequality': Studying Internet Use as Penetration Increases. Preuzeto 01. 12. 2017. s mrežne stranice Princeton Universityja: https://www.princeton.edu/ artspol/workpap/WP15 \%20- \%20DiMaggio $\% 2$ BHargittai.pdf.

DiMaggio, P., Hargittai, E., Coral, C., \& Shafer, S. (2004). From unequal access to differentiated use: A literature review and agenda for research on digital inequality. Preuzeto 01. 12. 2017. s Eszter Hargittai mrežne stranice: http://www.eszter.com/research/pubs/dimaggio-etal-digitalinequality.pdf.

Državni zavod za statistiku (2016). Primjena informacijskih $i$ komunikacijskih tehnologija (IKT) $u$ kućanstvima i kod pojedinaca u 2016. Preuzeto 12. 12. 2017. s mrežne stranice Državnog zavoda za statistiku: https://www.dzs.hr/Hrv_Eng/publication/2016/02-03-02_01_2016.htm.

Europska komisija (2013). DIGCOMP: A Framework for Developing and Understanding Digital Competence in Europe. Preuzeto 12. 12. 2017. s mrežne stranice Europske komisije: http://publications.jrc.ec.europa.eu/repository/bitstream/JRC83167/lb-na-26035-enn.pdf.

Europska komisija (2017a). Europe's Digital Progress Report 2017. Preuzeto 12. 12. 2017. s mrežne stranice Europske komisije: https://ec.europa.eu/digital-single-market/en/news/europes-digitalprogress-report-2017. 
Europska komisija (2017b). Izvješće o digitalnom razvoju Europe (EDPR) 2017.-profil države:Hrvatska. Preuzeto 16. 12. 2017. s mrežne stranice Europske komisije:

https://ec.europa.eu/digital-single-market/en/news/europes-digital-progress-report-2017.

EPRS European Parliamentary Research Service (2015). Bridging the Digital divide in the EU. Preuzeto 16. 12. 2017. s mrežne stranice Europskog parlamenta:

http://www.europarl.europa.eu/thinktank/en/document.html?reference=EPRS_BRI(2015)573884.

Eurostat (2017). Internet accesss and use statistics-households and individuals. Posjećeno 16. 12. 2017. na mrežnoj stranici Eurostata: http://ec.europa.eu/eurostat/statisticsexplained/index.php/Internet_access_and_use_statistics_-_households_and_individuals.

Haddon, L., Livingstone, S., EU Kids Online (2014). EU Kids Online: Annual Report 2014. Preuzeto 13. 12. 2017. s EU Kids Online mrežne stranice: http://www.lse.ac.uk/media@lse/research/EUKids Online/EU \%20Kids \%20I \%20(2006-9)/EU \%20Kids \%20Online \%20I \%20Reports/EUKidsOnline FinalReport.pdf.

Helsper, E. (2008). Digital inclusion: an analysis of social disadvantage and the information society. Preuzeto 01. 12. 2017. s LSE Research Online mrežne stranice: http://eprints.lse.ac.uk/26938/1/_libfi le_REPOSITORY_Content_Helsper, \%20E_Digital \%20inclusion_Helsper_Digital \%20inclusion_20 13.pdf.

Krištofić, B. (2007). Digitalna nejednakost. Sociologija i prostor 176(2), 165-181.

Stiakakis, E., Kariotellis, P. \& Vlachopoulou, M. (2009). From the Digital Divide to Digital Inequality: A Secondary Research in the European Union. Preuzeto 13. 12. 2017. s mrežne stranice Semantic Schoolara: https://pdfs.semanticscholar.org/54cf/f40419d8fe8c6a40c6590c324a4eaebc191d.pdf.

Smahel, D., Helsper, E., Green, L., Kalmus, V., Lukas Blinka, L., Ólafsson, K. (2012). Excessive internet use among European children. Preuzeto 13. 12. 2017. s EU Kids Online mrežne stranice: http://www.lse.ac.uk/media@1se/research/EUKidsOnline/EU \%20Kids \%20Online \%20reports.aspx.

Van Dijk, J. (2012). The Evolution of the digital Divide: The Digital Divide turns to Inequality of Skills and Usage. Preuzeto 06. 12. 2017. s mrežne stranice Universityja of Twente: https:// www.utwente.nl/en/bms/vandijk/news/The \%20Evolution \%20of \%20the \%20Digital \%20Divide/Evo lution \%20of \%20the \%20Digital \%20Divide \%20Digital \%20Enlightment \%20Yearbook \%202012.pdf.

Vrkić Dimić, J. (2014). Problem digitalne podjele. Nepredak 155(4), 419-433.

Primljeno: 30. srpnja 2018. godine

Prihvaćeno: 14 . kolovoza 2018. godine
Received: July 30, 2018

Accepted: August 14, 2018 